\title{
Expression of REG la gene in type 2 diabetics in Pakistan
}

\author{
Sadaf Saleem Uppal ${ }^{1 *}$, Abdul Khaliq Naveed ${ }^{2}$, Saeeda Baig ${ }^{3}$ and Bushra Chaudhry ${ }^{4}$
}

\begin{abstract}
Background: The escalating rate of diabetes' has prompted researchers around the world to explore for early markers. A deficit of functional $\beta$-cell mass plays a central role in the pathophysiology of type 2 diabetes. The REG (Regenerating) gene, encoding a 166 amino acid REG protein was discovered in rats and humans which is released in response to $\beta$-cells damage and play a role in their regeneration. The objective of this study was to characterize serum levels of REG la proteins in type 2 diabetic patients as indicator of $\beta$-cell apoptosis as well as regeneration.

Methods: Unrelated type 2 diabetic patients $(n=55)$ of different age groups and disease duration were recruited from the Medical OPD of PNS Shifa Hospital. Age and sex matched non diabetic controls $(n=20)$ without family history of diabetes were selected from the same setting. Demographical details were recorded on a structured questionnaire. Biochemical parameters like FBG, HbA1c, TC and TG levels were measured. Serum levels of REG la protein were determined by ELISA.

Results: Levels of REG la protein were found significantly raised in type 2 diabetic patients compared to controls $(p<001)$. Patients with short duration of the disease had higher levels of REG la as compared to patients with longer duration of the disease. Although the patients were on anti hyperglycemic agents, a positive correlation was found between REG la serum levels, FBG and HbA1c levels. Patients with higher BMI had higher levels of serum REG la levels. Serum TC, TG and Hb levels showed no correlation.

Conclusion: REG la may be used as a marker/predictor of type 2 diabetes especially in the early stages of the disease. Keywords: Type 2 diabetes, $\beta$-Cell regeneration, $\beta$-Cell apoptosis, REG la
\end{abstract}

\section{Background}

Pancreatic islet $\beta$-cells produce insulin which regulate body glucose metabolism, but their capacity for regeneration is limited, which plays a major role in the pathogenesis of autoimmune type 1 and insulin resistant type 2 diabetes [1]. An insufficiency in functional $\beta$-cell mass and their aptitude to secrete insulin is a characteristic feature of type 2 diabetes. Factors, other than renewal crisis, implicated in $\beta$-cell death in type 2 diabetes include glucolipotoxicity, amyloid deposits in pancreatic islet and high metabolic demand causing oxidative stress, endoplasmic reticulum stress as well as inflammatory

\footnotetext{
*Correspondence: sadaf@amcollege.nust.edu.pk

${ }^{1}$ Department of Biochemistry and Molecular Biology, Army Medical College, Rawalpindi and National University of Science and Technology, Islamabad, Pakistan

Full list of author information is available at the end of the article
}

signals such as cytokines production in the islet insulin producing cells have been associated with $\beta$-cell death in type 2 diabetes [2]. Future plan of action regarding prevention as well as treatment of diabetes should include such strategies that lead to amplify functional $\beta$-cell mass in pancreas $[3,4]$. A constant process of demise and restoration of $\beta$-cell mass is an ongoing process under physiological conditions [5]. For normal functioning of islets $\beta$-cells a crucial balance between these two processes appears to be obligatory. To date no methods for assessment of $\beta$-cell apoptosis in disease conditions in humans is available except for post mortem studies. These studies reported a deficit of up to sixty-five percent in pancreatic insulin producing cells in type 2 diabetes [6].

The novel REG (Regenerating) gene, encoding an approximately $17 \mathrm{kDa}$ protein was discovered during the screening of cDNA library derived from 
regenerating and hyperplastic islet in rats and humans [7]. The Reg1 protein, normally a product of acinar cells of exocrine pancreas has mitogenic effect on $\beta$-cells of endocrine pancreas and has been shown to improve experimental diabetes in rats [8-10]. Reg1 $\alpha$ protein causes replication of DNA in pancreatic $\beta$-cells and a receptor for Reg protein was identified that conveys a growth signal of Reg protein for regeneration of $\beta$-cells [11, 12]. In Reg knockout mice the size of islets were much smaller and they showed a lower proliferative capacity, while a delay in the onset of diabetes was observed in NOD mice carrying the Ins-Reg transgene [13], indicating a possible role of Reg family proteins in $\beta$-cell growth and regeneration. Reduction of Reg1 was linked with the pathogenesis of impaired glucose tolerance of diabetes [14], while treatment with Reg1 protein improved the islet $\beta$-cells ability to secrete insulin in rat models of diabetes, indicating its role in the pathogenesis of type 2 diabetes.

REG I $\alpha$ is one of the five members of the human REG family proteins and is encoded by a gene positioned on chromosome 2p12 [4]. REG protein levels are significantly increased in the islets from a diabetic patient, and antibodies against Reg protein which impede proliferation of $\beta$-cell are identified in the mouse models of diabetes [15] and in some diabetic patients [16], suggesting its role in the pathogenesis of human diabetes. This evidence led to the present hypothesis that REG proteins expression is enhanced during type 2 diabetes in their effort to regenerate islet $\beta$-cells destroyed due to glucolipotoxicity and increased metabolic demand. Therefore, the objective of this project was to characterize serum levels of REG I $\alpha$ proteins in patients of type 2 diabetes as markers of $\beta$-cell apoptosis and regeneration especially in the early stages of the disease.

\section{Methods}

\section{Subjects}

In this case control study unrelated patients (55) with diabetes were selected from the Medical OPD of PNS Shifa Hospital along with non-diabetic (20) controls. Prior to this the Ethical Committee of Army Medical College approved the study protocol. Blood samples $(10 \mathrm{ml})$ were collected after an informed consent for serum analysis from each subject. Blood sample was collected in clot activator tubes and was allowed to clot for $30 \mathrm{~min}$ before centrifugation for $30 \mathrm{~min}$ at $2500 \times g, 2-8{ }^{\circ} \mathrm{C}$. Serum was removed and stored in aliquots at $-20^{\circ} \mathrm{C}$ for ELISA and further analysis.

Serum REG I $\alpha$ protein levels were measured in 55 patients with type 2 diabetes with different age groups and disease duration and 20 normal sex/age matched controls. ADA criteria was used to assess the patients with type 2 diabetes [1]. Blood sample of each study subject was collected in the morning after an overnight fast. Height, weight, and blood pressure were measured. Biochemical analysis of blood was done for FBG, HbA1c, TC and TG.

\section{Quantification of serum REG la}

The REG I $\alpha$ protein was measured in serum of type 2 diabetics using a human REG I $\alpha$ BioAssay ELISA Kit (USBiological, life Science), which is a sandwich enzyme immunoassay for in vitro quantitative measurement of REG I $\alpha$ in human serum, plasma and other biological fluids. Samples were diluted 1:500 with 0.01 M PBS as follows: $20 \mu \mathrm{l}$ of sample were added to $180 \mu \mathrm{l}$ of PBS (dilution 1:10); $10 \mu \mathrm{l}$ of this dilution were pipetted into another $490 \mu \mathrm{l}$ of PBS to prepare the 1:500 dilutions as per requirement. In the BioAssay Human REG I $\alpha$ ELISA, $100 \mu \mathrm{l}$ of blank (PBS), standards and samples were added (in duplicates) in the wells of the microtiter strips coated with REG I $\alpha$ specific antibody. The microtiter plate was incubated at $25^{\circ} \mathrm{C}$ for $2 \mathrm{~h} .100 \mu \mathrm{l}$ of the Detection Reagent A working solution (Biotin-conjugated antibody specific to REG I $\alpha$ ) was added to each well and incubated for $1 \mathrm{~h}$ at $37^{\circ} \mathrm{C}$. Wells were washed three times with $1 \times$ wash solution. $100 \mu \mathrm{l}$ of the Detection Reagent B working solution [Avidin- conjugated with horseradish peroxidase (HRP)] was added to the wells and incubated for $30 \mathrm{~min}$ at $37{ }^{\circ} \mathrm{C}$. Wells were washed five times with wash solution and incubated with $90 \mu \mathrm{l}$ TMB substrate for $15 \mathrm{~min}$ at $37{ }^{\circ} \mathrm{C}$. After adding Stop Solution, reading was done at wavelength of $450 \mathrm{~nm}$ with a Microplate reader/spectrophotometer. A standard curve was created by plotting mean absorbance for each standard verses REG I $\alpha$ concentrations of the standards. The results are presented as REG $\mathrm{I} \alpha$ concentration $(\mathrm{pg} / \mathrm{ml})$ in the samples. The amount of REG I $\alpha$ in the blood sample of the patients was calculated by multiplying the result obtained by dilution factor 500 (for example, $62.5 \mathrm{pg} / \mathrm{ml} \times 500=31,250 \mathrm{pg}$ / $\mathrm{ml})$. Readings were converted to $\mathrm{ng} / \mathrm{ml}$ after multiplying by $0.001(31,250 \times 0.001=31.25)$. The antibodies used in this assay are specific for human REG I $\alpha$ with no known cross reactivities to recombinant human REG proteins.

\section{Statistical analysis}

Descriptive and inferential statistics were calculated. To check the normality of the data Shapiro-Wilk test were applied. Mean \pm SD OR median (inter quartile range) were calculated. The Mann-Whitney U test (for comparison of two groups) and Kruskal-Wallis test (for comparison of 3 or more than three groups) was used to compare quantitative variables. Spearman's rank test was used for analysis of correlation between variables. Unless otherwise indicated, $\mathrm{p}$ values of less than 0.05 were considered 
significant. Statistical analysis was performed using SPSS statistical software, version 16 .

\section{Results}

The clinical characteristics of the study subjects are shown in Table 1. Patients with type 2 diabetes had higher mean BMI, higher systolic blood pressure, higher FBG, HbA1c, fasting TC and TG levels as compared to the control subjects.

\section{Serum REG la protein levels}

Increased REG I $\alpha$ protein levels were detected in type 2 diabetes patients of different age groups and disease duration compared to age and sex matched controls with a p value of $<0.001$ (Fig. 1).

\section{Metabolic and risk factors correlation}

In type 2 diabetics, a negative correlation between disease duration and serum REG I $\alpha$ protein levels was observed ( $p=0.003$, Spearman $r=-0.39$ ) (Figs. 1b, 2a). Although the protein levels decreased with increase in the duration of the disease they remained significantly higher than the controls. Type 2 diabetes patients were divided into four groups according to the duration of disease. Group $1(\mathrm{n}=13)$ patients with duration of disease less than 2 years. Group $2(\mathrm{n}=14)$ patients with duration of disease $2-5$ years. Group $3(\mathrm{n}=14)$ patients

Table 1 Clinical characteristics of the study subjects

\begin{tabular}{|c|c|c|c|}
\hline Parameters & Control $(n=20)$ & Type $2(n=55)$ & $p$ value \\
\hline Sex, M/F & $12 / 8$ & $40 / 15$ & - \\
\hline Age (years) & $51 \pm 3$ & $55 \pm 9$ & - \\
\hline $\begin{array}{l}\text { Age at diagnosis of } \\
\text { disease (years) }\end{array}$ & - & $48.6 \pm 8.5$ & - \\
\hline $\begin{array}{l}\text { Duration of diabetes } \\
\text { (years) }\end{array}$ & - & $7.0 \pm 5.8$ & - \\
\hline $\mathrm{BMI}\left(\mathrm{kg} / \mathrm{m}^{2}\right)$ & $23.98 \pm 4.01$ & $25.5 \pm 3.9$ & $<0.032^{*}$ \\
\hline $\begin{array}{l}\text { Systolic blood pressure } \\
(\mathrm{mmHg})\end{array}$ & $120(110-120)$ & $130(120-140)$ & $<0.001^{* *}$ \\
\hline $\begin{array}{l}\text { Diastolic blood pressure } \\
(\mathrm{mmHg})\end{array}$ & $80(70-80)$ & $80(80-90)$ & $<0.001^{* *}$ \\
\hline $\mathrm{FBG}(\mathrm{mmol} / \mathrm{L})$ & $3.7(3.5-4.4)$ & $7.8(6.1-9.5)$ & $<0.001^{* *}$ \\
\hline HbA1c (\%) & $5.5(5.4-5.6)$ & $7.8(6.9-9.0)$ & $<0.001^{* *}$ \\
\hline $\mathrm{TC}(\mathrm{mmol} / \mathrm{L})$ & $3.7(3.2-4.7)$ & $5.1(4.5-5.6)$ & $<0.001^{* *}$ \\
\hline $\mathrm{TG}(\mathrm{mmol} / \mathrm{L})$ & $1.15(0.9-1.3)$ & $1.7(1.2-2.3)$ & $<0.041^{*}$ \\
\hline $\mathrm{Hb}(\mathrm{mg} / \mathrm{dL})$ & $13.2(12.6-14.2)$ & $12.0(11.6-12.8)$ & $<0.054$ \\
\hline
\end{tabular}

Data are given as mean \pm standard deviation for normally distributed variables, and otherwise as medians (inter quartile range). $P$ values of $\mathrm{BMI}$ was adjusted for age and sex. $P$ values of blood pressure, FBG, $\mathrm{HbA1C}$, and lipid profiles were adjusted for age, sex, and BMI

$B M I$ body mass index

$P$ values for differences between control group and type 2 diabetes patients. (* significant, ${ }^{* *}$ highly significant) with duration of disease 5-10 years. Group $4(n=14)$ patients with duration of disease more than 10 years. Significant difference was found between the four groups with $\mathrm{p}<0.05$. Between any two groups $\mathrm{p}$ value was calculated to be significant or non significant (Group 1 and $2 \mathrm{p}=0.23$ ), (Group 1 and $3 \mathrm{p}<0.05$ ), (Group 1 and $4 \mathrm{p}<0.05$ ), (Group 2 and $3 \mathrm{p}=0.31$ ), (Group 2 and 4 $\mathrm{p}=0.15)$ and (Group 3 and $4 \mathrm{p}=0.63$ ). Serum REG I $\alpha$ levels also showed a decline in their levels with increasing age of patient $(\mathrm{p}=0.019)$ (Fig. $2 \mathrm{~b})$.

Although the patients were on anti hyperglycemic agents, significant positive correlation was found between REG I $\alpha$ serum levels, FBG and HbA1c levels in type 2 diabetics (Fig. 2c, d). Serum cholesterol, serum triglycerides and hemoglobin levels in type 2 diabetics showed no correlation with circulatory REG I $\alpha$ levels. Risk factors like smoking and family history of diabetes also did not show any correlation with the REG I $\alpha$ serum levels in type 2 diabetics. Smokers have slightly higher levels of serum REG I $\alpha$ compared to the non smokers.

Systolic blood pressure $(\mathrm{p}=0.06)$ and diastolic blood pressure $(\mathrm{p}=0.16)$ were found directly proportional to increase in age, duration of the disease and decrease in REG I $\alpha$ protein levels.

Patients with increased body weight had higher levels of REG I $\alpha$ protein with a $\mathrm{p}$ value of 0.001 and Spearman $\mathrm{r}=0.42$ (Fig. 3).

\section{Discussion}

Worldwide there is scarcity of studies regarding role of REG I $\alpha$ in type 2 diabetes in humans. However, in the developing world where diabetes is becoming a leading cause of death, there are no exploratory studies. Pakistan now ranks seventh in terms of diabetes having 6.9 million cases of diabetes in 2014 according to International Diabetes Federation. A wide range of evidence suggests that a deficit of functional $\beta$-cell mass plays a key role in the pathophysiology of diabetes [17, 18] and expression of Reg genes following $\beta$-cell damage play a role in their regeneration and/or neogenesis [12].

In this study serum levels of REG I $\alpha$ protein were found significantly increased in type 2 diabetes patient compared to control subjects. The elevated levels of REG I $\alpha$ in the serum was observed in newly diagnosed patients with type 2 diabetes, and to a lesser degree, in patients with longer duration of the disease. Interestingly, type 2 diabetics with long term disease displayed relatively decreased REG I $\alpha$ levels and a negative correlation was observed between serum REG I $\alpha$ levels and disease duration. A negative correlation was also observed between serum REG I $\alpha$ levels and age of the type 2 diabetes patients. 


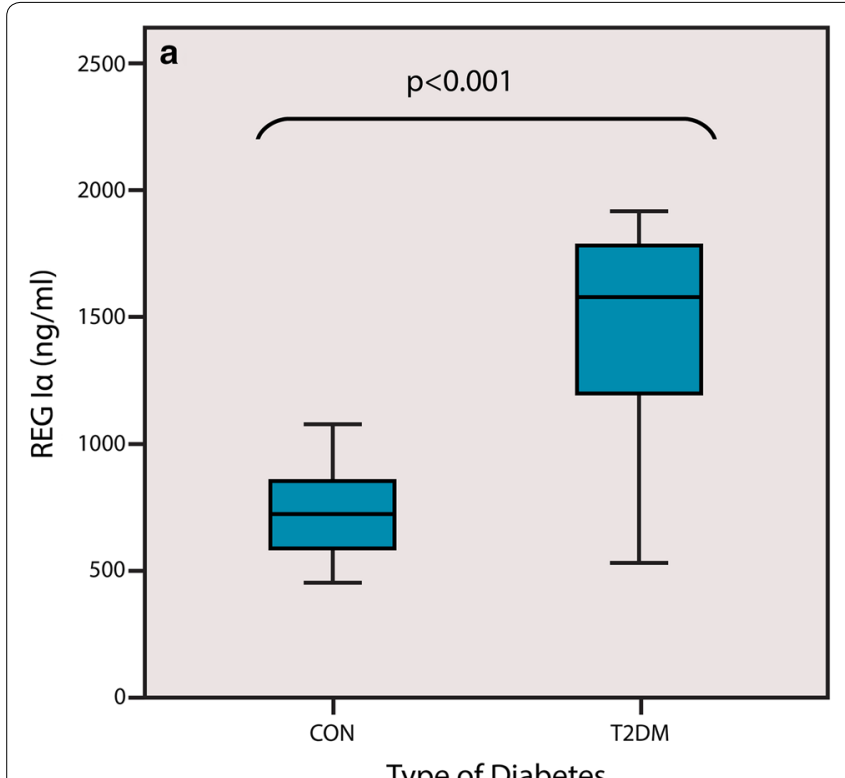

Type of Diabetes

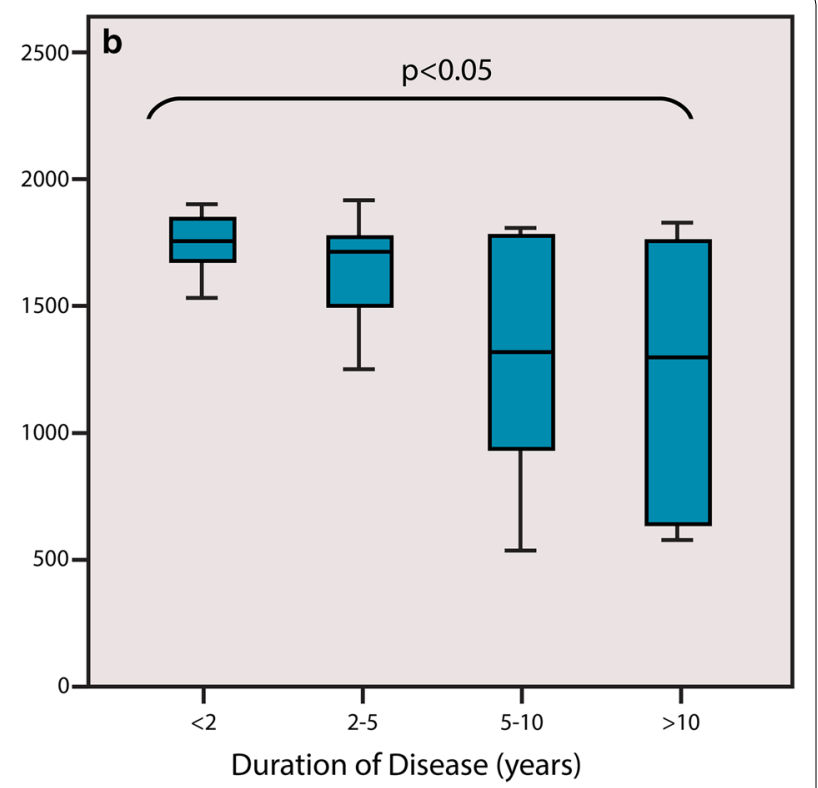

Fig. 1 Human REG la ELISA assay (USBiological, Life Sciences). Quantitative measurement of human REG la protein in serum. a Increased levels of REG la protein were observed in type 2 diabetes patients compared to controls $(p<0.001)$. b Serum REG la levels between different groups of type 2 diabetes patients. Significant relationship was found between the groups $p<0.05$

This study on REG I $\alpha$ is the first of its kind in type 2 diabetes patients of Pakistani background. Increased circulatory levels of REG I $\alpha$ in type 1 and type 2 diabetes patient was reported previously in a large scale study conducted in Caucasian population [19]. REG I $\alpha$ serum levels were also found elevated from third decade of life onwards in patients of maturity onset diabetes of the young (MODY) [20]. Our study also validate the previous widespread work done on experimental models of diabetes and pancreatic $\beta$-cell regeneration [13]. Reg1 expression was also demonstrated to be up regulated at very early stage in high fat diet induced mice models of obesity and type 2 diabetes [21]. This rise is the response of pancreas to hyperglycemia by enhancing the proliferation of pancreatic $\beta$-cells and their ability to secrete insulin.

It has been observed that damage to $\beta$-cells, due to their infiltration by immune cells, is responsible for up regulation of Reg1 genes expression [4]. The pathological role of inflammatory mechanism in obesity and type 2 diabetes has been reported by many studies in the last decade [22, 23]. In islets of spontaneous rat models of type 2 diabetes there was increased expression of Reg1 and Reg3 in association with peri-islet macrophage infiltration and release of various cytokines/chemokines, particularly IL-6. [24]. Addition of IL-6 and Dx together in human 1.1B4 $\beta$-cell lines induced REG I $\alpha$ and REG I $\beta$ expression [25]. An IL-6 response element has been identified in the promoter region of Reg1 gene and the local IL-6 levels plays a crucial role in influencing Reg gene expression [26]. A recent study has shown that apoptotic $\beta$-cells shed microparticles that stimulate expression of Reg1 $\alpha$ in neighboring cells, to facilitate $\beta$-cell regeneration thereby forming a link between $\beta$-cell apoptosis and $\beta$-cell regeneration. Moreover, the same study also demonstrated that extracellular high glucose concentration potentiates $R e g$ gene expression [27]. Increased serum levels of REG I $\alpha$ protein in patients with type 2 diabetes in present study is in agreement with the hypothesis that the deficit in $\beta$-cell mass due to increase in $\beta$-cell damage secondary to high metabolic demand and inflammation leads to upregulation of REG I $\alpha$ in regenerating $\beta$-cells and acinar cells.

On the contrary, increased REG I $\alpha$ levels have also been reported in conditions like Celiac disease [28], ventilator associated pneumonia [29] sepsis [30] and also in other conditions of inflammation and infections, however, the main source of REG I $\alpha$ remains to be pancreas. Moreover, at the time of sampling all such conditions other than diabetes which lead to raised serum Reg I $\alpha$ were excluded.

In the present study type 2 diabetics with long term disease demonstrated relatively decreased levels of REG $I \alpha$ and a negative association was found between serum REG I $\alpha$ levels and duration of disease. A negative correlation between circulatory REG I $\alpha$ protein and duration of disease has been previously reported in case of type 1 diabetics [19]. However, no correlation between age or disease onset and REG I $\alpha$ levels was found in 

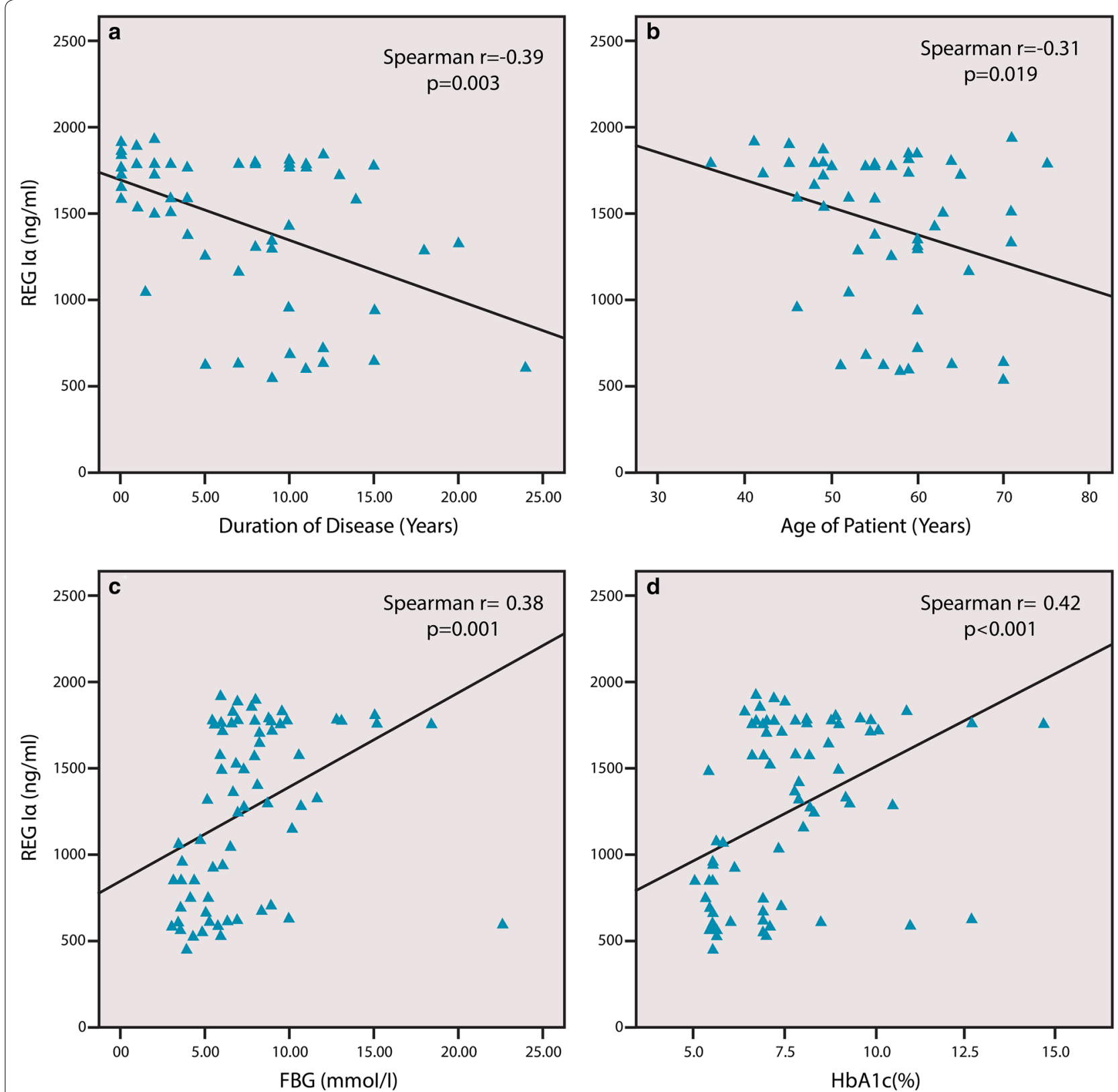

Fig. 2 Correlation between clinical characteristics and serum REG la protein in type 2 diabetes patients. a Correlation between disease duration and serum REG la protein. b Correlation between age of patient and serum REG la protein in type 2 diabetes patients. c Correlation between FBG and serum REG la protein in type 2 diabetes patients. $\mathbf{d}$ Correlation between HbA1c and serum REG la protein in type 2 diabetes patients

type 1 diabetics while raised REG I $\alpha$ levels were found in patients with MODY diagnosed in the third decade of life onwards as compared to those diagnosed earlier in life [20]. These patients had much less mean age compared to type 2 diabetics in our study. A recent pilot study conducted by Yang and colleagues reported significant upregulation of REG I gene in type 2 diabetes in accordance with our study, however, they related this increase with the clinical stages of the disease and its associated complication [31]. It has been reported that aging is associated with a decline in $\beta$-cells proliferation capacity [32]. A decline in the Reg1 expression has been observed in mice models during the normal aging process and agerelated islet dysfunction [33]. In the process of aging and pancreatitis-associated diabetes the decrease in acinar cells, the main source of Reg1 has been demonstrated [14]. In type 2 diabetes with the increase in the duration of disease a reduction in functional $\beta$-cell mass occurs 


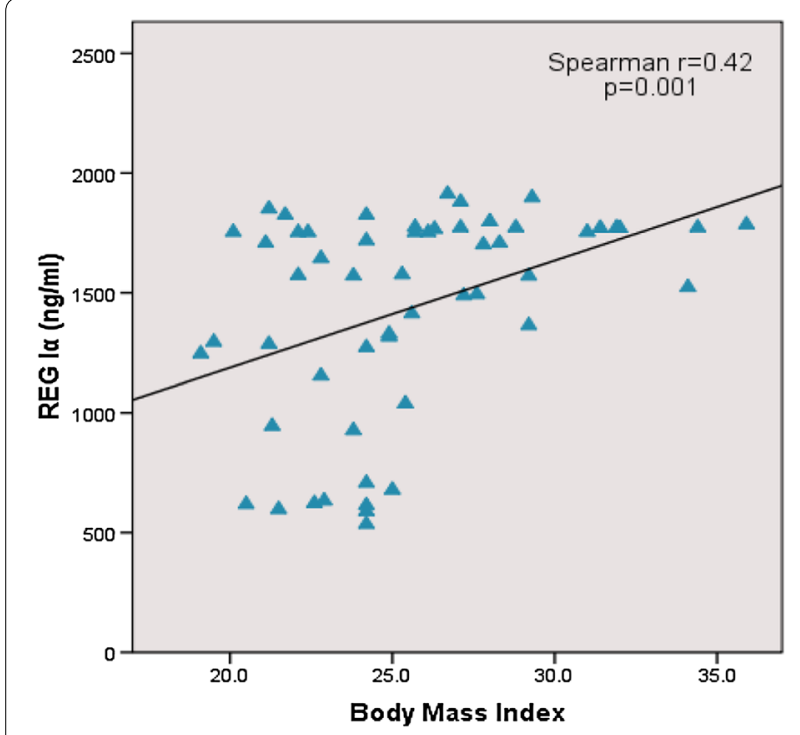

Fig. 3 Correlation between serum REG la and BMI in type 2 diabetes patients

[34], thus one-third of patients with long disease duration were found to be on insulin therapy. High intracellular levels of Reg I lead to inhibition of $\beta$-cell growth and possible induction of their apoptosis or differentiation into other cell types [35]. Thus, the relative decrease in REG I $\alpha$ levels with age and duration of the disease may be due to substantial damage to $\beta$-cells that occur in late stages of type 2 diabetes, decrease regeneration capacity of $\beta$-cells with age and age related decrease in acinar cells, the main source of REG I.

It was however interesting to find that the type 2 diabetes patients with longer duration of the disease and with known diabetic complications were found to have much higher REG I $\alpha$ levels (data not shown). The exact source of increase serum REG I $\alpha$ levels is unknown. REG I expression has been addressed as a defense mechanism to the inflammatory response. The other organs damaged/inflamed in these cases may possibly have contributed. Despite the fact that the patients were on anti-hypertensive medication, an increase in the systolic and diastolic blood pressure were observed. In patients with uncontrolled diabetes increased blood pressure is an important risk factor for death and disability [36]. Increased levels of Reg I $\alpha$ in response to $\beta$-cell damage has been associated with $\beta$-cell regeneration and increase in their insulin secretory capacity [8], leading to better control of diabetes and its associated risk factors. However, serum cholesterol, triglycerides and hemoglobin levels in type 2 diabetics in this study showed no correlation with circulatory REG I $\alpha$ levels. Interestingly, a positive though insignificant correlation between REG I $\alpha$ and smoking was observed. This is possibly due to nicotine in cigarettes, which is associated with apoptosis of $\beta$-cells [37] releasing REG I $\alpha$.

A significant correlation was found between serum REG I $\alpha, F B G$ and HbA1c levels in type 2 diabetics; higher REG I $\alpha$ levels had higher FBG and HbA1c levels. Studies have shown that high glucose concentration potentiates Reg gene expression [21, 27]. A recent study conducted by Yang also reported a positive correlation between REG I $\alpha$ and HbA1c levels in type 2 diabetics [31], while no correlation was found between REG I $\alpha$ and HbA1c levels in type1 diabetics and in patients with MODY $[19,20]$. One of the reasons behind reduced glycemic control in the early stages of the disease was the poor compliance of the patient due to lack of knowledge. Patients with increase BMI had higher serum levels of the Reg I $\alpha$ protein showing a positive correlation. Relative $\beta$-cell mass was demonstrated to be increased in obese versus lean, non diabetic subjects $[2,38]$. Obesity associated insulin resistance and hyperglycemia may be responsible for increase in the serum REG I $\alpha$ levels in this study.

\section{Conclusion}

In this study REG I $\alpha$ is demonstrated to be significantly upregulated in serum of type 2 diabetes patients, especially in patients of short duration of the disease and may be used as a marker of $\beta$-cell damage in type 2 diabetes in the early stages of the disease. Large scale studies in diabetic patients are required with different duration of the disease to further verify the significance of REG I $\alpha$ protein as an indicator of $\beta$-cell regeneration and/or $\beta$-cell apoptosis.

\section{Abbreviations}

ADA: American Diabetes Association; Dx: dexamethasone; ELISA: enzyme linked immunosorbent assay; FBG: fasting blood glucose; Hb: hemoglobin; HbA1c: glycosylated hemoglobin; IL-6: interleukin 6; NOD: non obese diabetic; OPD: outdoor patient department; PBS: phosphate buffer saline; TC: total cholesterol; TG: triglyceride.

\section{Authors' contributions}

Contributions in the conception and design: SSU, AKN, SB. Acquisition of data, or analysis and interpretation of data: SSU, BC. Preparation of the manuscript and critical review: SSU, SB. All authors read and approved the final manuscript.

\section{Author details}

${ }^{1}$ Department of Biochemistry and Molecular Biology, Army Medical College, Rawalpindi and National University of Science and Technology, Islamabad, Pakistan. ${ }^{2}$ Department of Biochemistry, Islamic International Medical College, Riphah International University, Islamabad, Pakistan. ${ }^{3}$ Department of Biochemistry, Ziauddin University, Karachi, Pakistan. ${ }^{4}$ Department of Biological and Biomedical Sciences, Aga Khan University, Karachi, Pakistan.

\section{Acknowledgements}

This study was supported by grant from National Institute of Science and Technology (NUST), Islamabad (Pakistan). I would like to thank Medical OPD of PNS Shifa Hospital for providing us with the diabetic patients and their Pathology Laboratory for collecting blood samples and analyzing the biochemical 
parameters. I am also thankful to CREAM Lab Army Medical College for allowing me to carry out ELISA Analysis.

\section{Competing interests}

The authors declare that they have no competing interests.

Received: 31 March 2015 Accepted: 2 November 2015

Published online: 13 November 2015

\section{References}

1. American Diabetes A. Diagnosis and classification of diabetes mellitus. Diabetes Care. 2010;33(Suppl 1):S62-9.

2. Meier JJ, Bonadonna RC. Role of reduced beta-cell mass versus impaired beta-cell function in the pathogenesis of type 2 diabetes. Diabetes Care. 2013;36(Suppl 2):S113-9.

3. Bernard-Kargar C, Ktorza A. Endocrine pancreas plasticity under physiological and pathological conditions. Diabetes. 2001;50(Suppl 1):S30-5.

4. Okamoto $\mathrm{H}$. The Reg gene family and Reg proteins: with special attention to the regeneration of pancreatic beta-cells. J Hepatobiliary Pancreat Surg. 1999;6(3):254-62.

5. Dor Y, Brown J, Martinez OI, Melton DA. Adult pancreatic beta-cells are formed by self-duplication rather than stem-cell differentiation. Nature. 2004:429(6987):41-6.

6. Matveyenko AV, Butler PC. Relationship between beta-cell mass and diabetes onset. Diabetes Obes Metab. 2008;10(Suppl 4):23-31.

7. Terazono K, Yamamoto H, Takasawa S, Shiga K, Yonemura Y, Tochino Y, Okamoto $\mathrm{H}$. A novel gene activated in regenerating islets. J Biol Chem. 1988;263(5):2111-4

8. Watanabe $T$, Yonemura $Y$, Yonekura H, Suzuki Y, Miyashita H, Sugiyama K, Moriizumi S, Unno M, Tanaka O, Kondo H, Bone AJ, Takasawa S, Okamoto $H$. Pancreatic beta-cell replication and amelioration of surgical diabetes by Reg protein. Proc Natl Acad Sci USA. 1994;91(9):3589-92.

9. Zenilman ME, Magnuson TH, Swinson K, Egan J, Perfetti R, Shuldiner AR. Pancreatic thread protein is mitogenic to pancreatic-derived cells in culture. Gastroenterology. 1996;110(4):1208-14.

10. Levine JL, Patel KJ, Zheng Q, Shuldiner AR, Zenilman ME. A recombinant rat regenerating protein is mitogenic to pancreatic derived cells. J Surg Res. 2000;89(1):60-5.

11. Kobayashi S, Akiyama T, Nata K, Abe M, Tajima M, Shervani NJ, Unno M, Matsuno S, Sasaki H, Takasawa S, Okamoto H. Identification of a receptor for reg (regenerating gene) protein, a pancreatic beta-cell regeneration factor. J Biol Chem. 2000;275(15):10723-6.

12. Okamoto $\mathrm{H}$, Takasawa S. Recent advances in the Okamoto model: the CD38-cyclic ADP-ribose signal system and the regenerating gene protein (Reg)-Reg receptor system in beta-cells. Diabetes. 2002;51(Suppl 3):S462-73.

13. Unno M, Nata K, Noguchi N, Narushima Y, Akiyama T, Ikeda T, Nakagawa K, Takasawa S, Okamoto H. Production and characterization of Reg knockout mice: reduced proliferation of pancreatic beta-cells in Reg knockout mice. Diabetes. 2002;51(Suppl 3):S478-83.

14. Bluth M, Mueller CM, Pierre J, Callender G, Kandil E, Viterbo D, Fu SL, Sugawara A, Okamoto H, Zenilman ME. Pancreatic regenerating protein I in chronic pancreatitis and aging: implications for new therapeutic approaches to diabetes. Pancreas. 2008;37(4):386-95.

15. Gurr W, Yavari R, Wen L, Shaw M, Mora C, Christa L, Sherwin RS. A Reg family protein is overexpressed in islets from a patient with new-onset type 1 diabetes and acts as T-cell autoantigen in NOD mice. Diabetes. 2002:51(2):339-46.

16. Shervani NJ, Takasawa S, Uchigata Y, Akiyama T, Nakagawa K, Noguchi N, Takada H, Takahashi I, Yamauchi A, Ikeda T, Iwamoto Y, Nata K, Okamoto H. Autoantibodies to REG, a beta-cell regeneration factor, in diabetic patients. Eur J Clin Invest. 2004;34(11):752-8.

17. Butler AE, Janson J, Bonner-Weir S, Ritzel R, Rizza RA, Butler PC. Beta-cell deficit and increased beta-cell apoptosis in humans with type 2 diabetes. Diabetes. 2003;52(1):102-10.

18. Saisho Y. beta-cell dysfunction: its critical role in prevention and management of type 2 diabetes. World J Diabetes. 2015;6(1):109-24.
19. Astorri E, Guglielmi C, Bombardieri M, Alessandri C, Buzzetti R, Maggi D, Valesini G, Pitzalis C, Pozzilli P. Circulating Reg1alpha proteins and autoantibodies to Reg1alpha proteins as biomarkers of beta-cell regeneration and damage in type 1 diabetes. Horm Metab Res. 2010;42(13):955-60.

20. Bacon S, Kyithar MP, Schmid J, Rizvi SR, Bonner C, Graf R, Prehn JH, Byrne MM. Serum levels of pancreatic stone protein (PSP)/reg1A as an indicator of beta-cell apoptosis suggest an increased apoptosis rate in hepatocyte nuclear factor 1 alpha (HNF1A-MODY) carriers from the third decade of life onward. BMC Endocrine Disorders. 2012;12:13.

21. Qiu L, List EO, Kopchick JJ. Differentially expressed proteins in the pancreas of diet-induced diabetic mice. Mol Cell Proteom MCP. 2005;4(9):1311-8.

22. Donath MY. Targeting inflammation in the treatment of type 2 diabetes: time to start. Nat Rev Drug Discov. 2014;13(6):465-76.

23. Wang X, Bao W, Liu J, Ouyang YY, Wang D, Rong S, Xiao X, Shan ZL, Zhang Y, Yao P, Liu LG. Inflammatory markers and risk of type 2 diabetes: a systematic review and meta-analysis. Diabetes Care. 2013;36(1):166-75.

24. Calderari S, Irminger JC, Giroix MH, Ehses JA, Gangnerau MN, Coulaud J, Rickenbach K, Gauguier D, Halban P, Serradas P, Homo-Delarche F. Regenerating 1 and $3 \mathrm{~b}$ gene expression in the pancreas of type 2 diabetic Goto-Kakizaki (GK) rats. PLoS One. 2014;9(2):e90045.

25. Yamauchi A, Itaya-Hironaka A, Sakuramoto-Tsuchida S, Takeda M, Yoshimoto K, Miyaoka T, Fujimura T, Tsujinaka H, Tsuchida C, Ota H. Synergistic activations of REG la and REG I $\beta$ promoters by IL-6 and glucocorticoids through JAK/STAT pathway in human pancreatic $\beta$ cells. J Diabetes Res. 2015;2015:173058.

26. Akiyama T, Takasawa S, Nata K, Kobayashi S, Abe M, Shervani NJ, Ikeda T, Nakagawa K, Unno M, Matsuno S, Okamoto H. Activation of Reg gene, a gene for insulin-producing beta -cell regeneration: poly(ADP-ribose) polymerase binds Reg promoter and regulates the transcription by autopoly(ADP-ribosyl)ation. Proc Natl Acad Sci USA. 2001;98(1):48-53.

27. Bonner C, Bacon S, Concannon CG, Rizvi SR, Baquie M, Farrelly AM, Kilbride SM, Dussmann H, Ward MW, Boulanger CM, Wollheim CB, Graf R, Byrne MM, Prehn JHM. INS-1 cells undergoing caspase-dependent apoptosis enhance the regenerative capacity of neighboring cells. Diabetes. 2010;59(11):2799-808

28. Vives-Pi M, Takasawa S, Pujol-Autonell I, Planas R, Cabre E, Ojanguren I, Montraveta M, Santos AL, Ruiz-Ortiz E. Biomarkers for diagnosis and monitoring of celiac disease. J Clin Gastroenterol. 2013;47(4):308-13.

29. Boeck L, Graf R, Eggimann P, Pargger H, Raptis DA, Smyrnios N, Thakkar N, Siegemund M, Rakic J, Tamm M, Stolz D. Pancreatic stone protein: a marker of organ failure and outcome in ventilator-associated pneumonia. Chest. 2011;140(4):925-32.

30. Keel M, Harter L, Reding T, Sun LK, Hersberger M, Seifert B, Bimmler D, Graf R. Pancreatic stone protein is highly increased during posttraumatic sepsis and activates neutrophil granulocytes. Crit Care Med. 2009;37(5):1642-8.

31. Yang J, Li L, Raptis D, Li X, Li F, Chen B, He J, Graf R, Sun Z. Pancreatic stone protein/regenerating protein (PSP/reg): a novel secreted protein upregulated in type 2 diabetes mellitus. Endocrine. 2015;48(3):856-62.

32. De Tata V. Age-related impairment of pancreatic Beta-cell function: pathophysiological and cellular mechanisms. Front Endocrinol. 2014;5:138.

33. Perfetti R, Egan JM, Zenilman ME, Shuldiner AR. Differential expression of reg-I and reg-II genes during aging in the normal mouse. J Gerontol Ser A Biol Sci Med Sci. 1996;51(5):B308-15

34. Lencioni $C$, Lupi R, Del Prato $S$. Beta-cell failure in type 2 diabetes mellitus. Curr DiabRep. 2008;8(3):179-84

35. Mueller CM, Zhang H, Zenilman ME. Pancreatic reg I binds MKP-1 and regulates cyclin D in pancreatic-derived cells. J Surg Res. 2008;150(1):137-43

36. Campbell NR, Gilbert RE, Leiter LA, Larochelle P, Tobe S, Chockalingam A, Ward R, Morris D, Tsuyuki RT, Harris SB. Hypertension in people with type 2 diabetes: update on pharmacologic management. Can Fam Phys. 2011;57(9):997-1002, e347-53.

37. Xie XT, Liu Q, Wu J, Wakui M. Impact of cigarette smoking in type 2 diabetes development. Acta Pharmacol Sin. 2009;30(6):784-7.

38. Butler AE, Janson J, Soeller WC, Butler PC. Increased beta-cell apoptosis prevents adaptive increase in beta-cell mass in mouse model of type 2 diabetes: evidence for role of islet amyloid formation rather than direct action of amyloid. Diabetes. 2003;52(9):2304-14. 